\title{
ROLA SPOLECZEŃSTWA OBYWATELSKIEGO W PROWADZENIU POLITYKI ROZWOJU LOKALNEGO
}

\section{Wstęp}

Poziom rozwoju lokalnego determinowany jest w dużej mierze przyjętym sposobem zarządzania. Dla optymalizacji efektów działalności współczesne władze samorządowe winny przyjmować nowoczesne metody maksymalnie wykorzystujące dostępne zasoby, uwzględniające szczególną rolę kapitału ludzkiego i społecznego. Rzeczywistymi podmiotami rozwoju lokalnego w dobie decentralizacji są, obok władz lokalnych, także mieszkańcy, jednostki gospodarcze oraz organizacje non-profit funkcjonujące w samorzadach lokalnych. Autorka wskazuje w artykule rolę społeczności obywatelskiej i celowość jej współdziałania $\mathrm{z}$ władzami lokalnymi. Połączenie zasobów wszystkich członków społeczności daje bowiem efekty synergiczne rozwoju.

\section{Polityka rozwoju lokalnego}

Termin polityka rozumiany jest tu bardzo szeroko: od sztuki dokonywania wyborów, przyjmowania kompromisów, procesu zmierzającego do urzeczywistniania wizji, po ogólne jej określenie jako czynności i zamierzeń dokonywanych przez decydentów dla osiągnięcia określonych celów z wykorzystaniem odpowiednich narzędzi ${ }^{1}$. Odnosząc powyższą definicję do polityki rozwoju lokalnego określić ją można jako celową działalność władz za pomocą dobranych metod i środków, nakierowaną na rozwój i osiągnięcie postawionych zamierzeń, którymi są pozytywne, świadomie inicjowane przemiany zachodzące w jednostce samorządowej.

Polityka rozwoju lokalnego jest dziedziną, której efekty nie są zazwyczaj zauważalne natychmiast. Jest to polityka drobnych kroków, które - ujęte kompleksowo - mają duże znaczenie dla społeczności lokalnej. Bieżące działa-

\footnotetext{
Doktorantka, Katedra Gospodarki Regionalnej i Środowiska, Wydział Ekonomiczno-Socjologiczny UŁ.

${ }^{1}$ A. Nowakowska, Polityka rozwoju gminy w okresie transformacji systemowej, [w:] A. Jewtuchowicz (red.), Strategiczne problemy rozwoju miast i regionów, Zakład Ekonomiki Regionalnej i Ochrony Środowiska UŁ, Łódź 2000, s. 11-12, cyt. za: M. Chamaj, W. Sokół (red.), Mały leksykon politologiczny, Lublin 1997.
} 
nia kształtujące rozwój społeczno-gospodarczy stymulowane są chęcią optymalizacji funkcjonowania jednostki $\mathrm{w}$ zmiennym otoczeniu oraz naturalnymi oczekiwaniami poprawy poziomu życia społeczności.

Samodzielność wspólnoty w prowadzeniu polityki rozwoju wynika z istoty samorządów terytorialnych, czyli gospodarowania na własnym terenie, włączając $\mathrm{w}$ to również obowiązki $\mathrm{w}$ zakresie kształtowania środowiska lokalnego. Na efekty prowadzenia własnych polityk przez poszczególne jednostki samorządowe duży wpływ mają zatem czynniki endogeniczne, do których zaliczyć należy profesjonalizm i podejście władz do przyjmowania efektywnych metod zarządzania, a także aktywność społeczności obywatelskiej. Kluczową rolę w rozwoju lokalnym odgrywają władze lokalne poprzez monitorowanie zachodzących zjawisk i procesów wewnętrznych i zewnętrznych oraz koordynowanie działań środowisk lokalnych zgodnych ze społecznie akceptowaną i przyjętą strategią.

Założeniem przedsięwzięć mających na celu rozwój lokalny jest dążenie do osiągania korzyści przez członków społeczności. Najwłaściwszym zatem podejściem w inicjowaniu tychże działań jest wskazywanie potrzeb i problemów przez same władze samorządowe lub lokalne podmioty związane terytorialnie i tożsamościowo. Funkcjonując w danej wspólnocie najlepiej znają one problemy społeczno-gospodarcze danego obszaru, przy czym właściwie do potrzeb i możliwości określą optymalne kierunki rozwoju i sposoby realizacji zadań. Prawidłowo prowadzona polityka rozwoju w konkretnej jednostce winna uwzględniać i wykorzystywać zarówno dostępne instrumenty przydatne w jej optymalizowaniu, jak i maksimum dostępnych kapitałów, włączając w nie przede wszystkim zasoby kapitału społecznego, które pozwalają na trafne i szybkie reagowanie na zmieniające się warunki.

\subsection{Podmioty polityki rozwoju lokalnego}

Jak już wcześniej wspomniano, polityka rozwoju lokalnego opiera się na świadomej działalności sfery publicznej wspólnoty. Głównym więc podmiotem polityki są władze samorządowe stymulujące rozwój poprzez dostępne instrumenty, kształtowanie postaw i utrwalanie w świadomości osób publicznych ich misji i powierzonych im ról ${ }^{2}$. Są one równocześnie ośrodkiem decyzyjnym i muszą podejmować niezależne, obiektywne i racjonalne postanowienia, decyzje i działania. Oznacza to, że wymogiem ich podmiotowości są

\footnotetext{
${ }^{2}$ A. Potoczek, Administracja publiczna w procesie zarzadzania rozwojem lokalnym i regionalnym, [w:] J. Rutkowski, D. Stawasz (red.), Zarzadzanie rozwojem lokalnym, Fundacja Współczesne Zarządzanie, Białystok 2005, s. 84.
} 
m.in. zasady samodzielności i samorządności zapewnione w obowiązującym prawie ${ }^{3}$.

Rzetelne podejście do zarządzania rozwojem lokalnym wymaga dobrej wiedzy o dostępnych, szeroko pojętych zasobach, możliwościach oraz o zachodzących procesach społeczno-gospodarczych i ich skutkach. Jednym z warunków bycia dobrym gospodarzem, kreatorem przyszłości gminy czy powiatu jest znajomość nie tylko samej jednostki, ale także bliższego i dalszego otoczenia, zewnętrznych ograniczeń, a także szans determinujących rozwój lokalny ${ }^{4}$.

Efektywne gospodarowanie wymaga od władz stosowania nowoczesnych sposobów i możliwości działań z optymalnym wykorzystywaniem dostępnych zasobów, do jakich zaliczyć należy lokalny kapitał społeczny, aktywizujący obywateli do uczestnictwa w działaniach na rzecz wspólnoty. Decentralizacja spowodowała scedowanie realizacji zadań publicznych z dbałością o rozwój lokalny na podmioty będące jak najbliżej obywatela. W szerokim kontekście założenie to przypisuje podmiotowość nie tylko władzom lokalnym, lecz także samej społeczności mającej $\mathrm{w}$ dużej mierze pożądane cechy podmiotów odpowiedzialnych za proces rozwoju lokalnego. Najpilniejsze potrzeby wynikające $\mathrm{z}$ niedogodności życia codziennego lub aspiracji wprowadzania innowacji najtrafniej mogą bowiem ocenić i wskazać sami zainteresowani. Tworzenie płaszczyzn współdziałania wielości środowisk lokalnych, znających i reprezentujących różne dziedziny oraz sfery wspólnoty łączy kapitały, które stanowią bogate źródło wiedzy zarówno o zasobach jednostki, jak i możliwościach ich wykorzystania. Podmiotem polityki rozwoju jest zatem cała zaangażowana $\mathrm{w}$ tenże rozwój społeczność lokalna partnersko współdecydująca o rodzajach działań, a więc środowiska gospodarcze, organizacje i środowiska społeczne. Podmiotem mogą być także osoby będące uczestnikami zewnętrznymi, ale mającymi wpływ na rozwój lokalny danego terytorium. Należą do nich publiczni decydenci regionalni i krajowi, inwestorzy, zarządy wielkich firm czy banków ${ }^{5}$.

Zachęcanie do współpracy inicjować może organizowanie debat na ważne dla wspólnoty tematy, a także prezentacji czy bezpośrednich paneli informacyjno-dyskusyjnych. Wytworzenie przyjaznej atmosfery sprzyjać będzie trafnemu wskazaniu priorytetów i skupieniu maksymalnej liczby zainteresowa-

\footnotetext{
${ }^{3}$ Ustawa z dnia 8 marca 1990 roku o samorządzie gminnym, DzU, 1990, nr 16, poz. 95, z późn. zm.; Ustawa 5 czerwca 1998 roku o samorządzie powiatowym, DzU, 1988, nr 91, poz. 578 , z późn. zm.

${ }^{4}$ A. Nowakowska, Polityka rozwoju gminy..., s. 13-15.

${ }^{5} \mathrm{~W}$. Zasadzki, Wybrane problemy lokalnej i regionalnej polityki gospodarczej, [w:] J. Kaja, K. Piech (red.), Rozwój oraz polityka regionalna i lokalna w Polsce, Szkoła Główna Handlowa w Warszawie, Warszawa 2005, s. 24.
} 
nych wokół rozwiązań problemu. Władze szczebla lokalnego winny czuć się gospodarzem i koordynatorem działań kompleksowych, ujmowanych z punktu widzenia przyjętych wartości i realizowanych dzięki współpracy środowisk zaangażowanych.

\subsection{Przedmiot polityki rozwoju lokalnego}

Przedmiotem polityki rozwoju lokalnego jest terytorium wraz z zachodzącymi na nim procesami, będącymi efektem relacji zachodzących między różnorodnymi sferami. Stanowią one bazę rozwoju tego obszaru, natomiast przestrzeń i jej zagospodarowanie są punktem wyjścia tejże polityki.

Ograniczoność powierzchni oraz świadomość władania i zarządzania nią przez wspólnotę, którą łączą więzi tożsamości i odpowiedzialności, a także przyjęte wspólne wartości i cele, sprawia, że na jednostkę samorządową jako na przedmiot polityki rozwoju lokalnego spojrzeć należy pod szerokim kątem, nie tylko jako na przestrzeń, infrastrukturę i przyrodę, ale również na stosunki i relacje zachodzące między wszystkimi elementami wewnętrznymi, jak też związanymi $\mathrm{z}$ otoczeniem zewnętrznym. Można traktować gminę czy powiat jako złożony lokalny terytorialny system społeczny, na który składają się infrastruktura, podmioty gospodarcze wraz $\mathrm{z}$ zapleczem materialnym oraz produkcyjnym, a także sami mieszkańcy napędzający funkcjonowanie tego systemu. Zatem sam przedmiot polityki rozwoju lokalnego traktowany jest w wielu aspektach dotyczących każdego ze składników systemu pod kątem widzenia prowadzenia różnozakresowych polityk. Samorząd taki stanowi więc w pewnym sensie jednostkę autonomiczną, $\mathrm{z}$ władzą i społecznością realizującymi samodzielnie wytyczone cele. Stopień autonomii lokalnej, oprócz determinantów egzogenicznych, określają uwarunkowania wewnętrzne, do których zaliczyć należy istniejący potencjał społeczno-gospodarczy czy różnorodne więzi ${ }^{6}$.

Polityka rozwoju lokalnego zależna jest od podstaw prawno-ustrojowych, a także warunków środowiskowo-społeczno-gospodarczych, od istnienia różnego rodzaju zasobów, potrzeb, aspiracji i uznanych wartości środowiska lokalnego oraz wszelkich barier. W ramach tejże polityki samorządy prowadzą wcześniej wspomniane, indywidualnie kształtowane rodzaje polityk poszczególnych sfer rozwoju jednostki terytorialnej. Do zbioru tego należą polityki: społeczna, gospodarcza, finansowa, przestrzenna, informacyjna czy wspierania przedsiębiorczości. Efektywnie i spójnie prowadzone polityki wpływając na sprawność zaspokajania potrzeb i oczekiwań społeczności rodzą aktywność społeczną, która w znacznym stopniu przyczynia się do szybszego rozwoju społeczno-gospodarczego jednostki terytorialnej.

\footnotetext{
${ }^{6}$ J.J. Parysek, Podstawy gospodarki lokalnej, Wyd. Nauk. UAM, Poznań, 2001, s. 26-29.
} 


\section{Istota pojęcia „kapital społeczny”}

W dobie decentralizacji coraz większego znaczenia w trosce o stały rozwój nabierają czynniki oparte na wzajemnym zaufaniu i współpracy. Są one wartością lokalną, tworząc rodzaj kapitału, który wpływa na gospodarkę podmiotów tu funkcjonujących, jak również na rozwój i gospodarkę całego obszaru.

Pojęcie kapitału społecznego, sformułowane po raz pierwszy w roku 1916 przez Amerykanina L.F. Hanifau, przez długie lata traktowane było marginalnie. Jego znaczenie i rangę ugruntowali dopiero w drugiej połowie lat 80 . XX w. w czasie swych badań James Coleman i Pierre Bourdieu. Od tego momentu interesowali się nim socjolodzy i ekonomiści. P. Bourdieu określił „kapitał społeczny" jako związki i zobowiązania międzyludzkie, które można oszacować. Według niego kapitał taki, to obok kapitału ekonomicznego i kapitału kulturowego, element ogólnego pojęcia „kapitał”. J. Coleman przedstawił kapitał społeczny poprzez pełnione przezeń funkcje i odgrywaną rolę. Stwierdził, że istotną cechą jest jego wartość osiągana przez relacje i dążenia powiązanych ze sobą jednostek społecznych ${ }^{7}$. Przynależność do danej struktury powoduje wśród jej członków poczucie współodpowiedzialności i solidaryzmu oraz aktywizuje ich do wspólnych działań dających efekty synergiczne. Inne jest spojrzenie na pojęcie „kapitał społeczny” R. Putnama, który określił ten kapitał poprzez pryzmat zaufania, jako jego części składowej, które ułatwia współpracę, sprzyja redukcji kosztów transakcyjnych, co z kolei przyczynia się do efektywności samej gospodarki, a także efektywności zarządzania ${ }^{8}$.

Istotę kapitału społecznego stanowią normy, wartości oraz zdolność tworzenia i aktywności sieci obywatelskich, a on sam uznany został za specyficzny zasób lokalny. Produktywność kapitału społecznego umożliwia realizację takich zamierzeń, które bez jego udziału byłyby trudne lub wręcz niemożliwe do osiągnięcia. Działania zainteresowanych grup społecznych, reprezentujących różnorodne dziedziny wiedzy i potencjału są bowiem nieocenione i nieporównywalne $\mathrm{z}$ działaniami jednostek. Współpraca określonego środowiska dla osiągnięcia zamierzonego celu pozwala na szybką reakcję i dostosowanie do zmiennych warunków. Kapitał społeczny i możliwość uczestniczenia społeczności $\mathrm{w}$ procesach decyzyjnych kojarzona jest z pojęciem „governance”. Jest to idea regulacji wskazująca jako kluczową szeroką analizę i wykorzystywanie wewnętrznych czynników sprzyjających stymulacji społeczno-gospodarczej’.

${ }^{7}$ Z. Przygodzki, Znaczenie kapitału społecznego w rozwoju, [w:] A. Jewtuchowicz (red.), Wiedza, innowacyjność, przedsiębiorczość a rozwój regionów, Wyd. UŁ, Łódź 2004, s. 97-98.

${ }^{8}$ A. Rymsza, Klasyczne koncepcje kapitału społecznego, [w:] T. Kaźmierczak, M. Rymsza (red.), Kapitat społeczny. Ekonomia społeczna, Instytut Spraw Publicznych, Warszawa 2007, s. $30-38$.

${ }^{9}$ A. Jewtuchowicz, Terytorium i współczesne dylematy jego rozwoju, Wyd. UŁ, Łódź 2005, s. 119-123. 
Nowoczesne paradygmaty rozwoju lokalnego związane z koncepcją zasobów lokalnych, obok więzi społeczności dodają też tezę budowania związków społecznych łączących się z realizacją wspólnych interesów przez różnego typu ruchy i akcje. Można więc stwierdzić, że w kontekście stwarzania poczucia odpowiedzialności za wspólnotę, mieszkańców nie muszą łączyć głębokie kontakty bezpośrednie, ale znajomość i rozumienie historii społeczności, uwarunkowań jej rozwoju oraz bieżących potrzeb i problemów ${ }^{10}$.

Efekty wykorzystania lokalnego kapitału ludzkiego i społecznego w pracy zespołowej przewyższają rezultat działań indywidualnych, mają zatem znaczący wpływ na szybsze tempo rozwoju i sytuację ekonomiczną danej jednostki. Połączenie szeregu doświadczeń $\mathrm{z}$ wiedzą wielu dziedzin, jakie reprezentują aktorzy lokalni, oraz ich inwencja twórcza stanowić mogą podstawę konstrukcji innowacyjnych technik efektywnego zarządzania w samorządach.

\section{Ksztaltowanie i misja społeczeństwa obywatelskiego}

Na przestrzeni lat oddolne inicjatywy społeczne na ziemiach polskich pojawiały się z różnym nasileniem, zależnym od warunków i sytuacji. Aktywność ta ma długą tradycję, gdyż już w średniowieczu zakładano fundacje klasztorne. W latach zaborów z kolei intensywnie działały organizacje konspiracyjne będące w opozycji do zaborcy, a propagujące polskość, tradycje kulturowe, etniczne, tworzące zalążek obywatelskości, partnerstwa i wspólnych celów. Podobnie przedstawia się aktywność i poczucie przynależności i odpowiedzialności wspólnot w latach powojennych, kiedy to aż do roku 1956 wszelkie organizacje i inicjatywy pozapartyjne i pozarządowe były zlikwidowane lub znacjonalizowane i aktywność społeczeństwa obywatelskiego nie miała szans zaistnienia. Ten przełomowy rok przyniósł zmiany w postaci możliwości organizowania się, choć pod ścisłą kontrolą władz. Lata socjalizmu, charakteryzujące się centralnym systemem planowania i zarządzania gospodarczego oraz hierarchiczną zależnością i podejmowaniem odgórnych decyzji kształtujących rozwój lokalny, sprzyjały rozluźnieniu więzi i solidaryzmu lokalnych aktorów i brakowi zaangażowania we wspólne działania. Zmiany, jakie nastąpiły po transformacji ustrojowej po roku 1990 wprowadziły samorządy lokalne na drogę samodzielnego decydowania o własnym funkcjonowaniu i rozwoju. Początkiem odradzania się społeczeństwa obywatelskiego były przedsięwzięcia wymierzone przeciw rządom komunistycznym, zainicjowane powstaniem Solidarności w roku $1980^{11}$. Związane z nią lokalne i ogólnokrajowe ruchy spowodowały proces reformowa-

${ }^{10}$ B. Lewenstein, Nowe paradygmaty rozwoju ukladów lokalnych, [w:] J. Kurczewska (red.), Oblicza lokalności. Różnorodność miejsc i czasu, Wyd. IFiS PAN, Warszawa 2006, s. 226-228.

${ }^{11}$ M. Ziółkowski, Społeczeństwo obywatelskie, transformacja i tradycja we wspólnotach lokalnych, [w:] K. Bondyra, M.S. Szczepański, P. Śliwa (red.), Państwo, samorzq̨d i spoleczności lokalne. Piotr Buczkowski in memoriam, Wyd. WSB w Poznaniu, Poznań 2005, s. 37-42. 
nia gospodarki. Jednak zapał do inicjatyw związkowych osłabł po ich upolitycznieniu i przejściu czołowych działaczy do świata polityki.

Czynny udział społeczności w działalności publicznej i w kształtowaniu dróg funkcjonowania jednostek samorządowych wiąże się $\mathrm{z}$ pojęciem społeczeństwa obywatelskiego ${ }^{12}$. Określenie to zdefiniować można jako samodzielne, spontaniczne organizowanie się społeczeństwa, które chcąc mieć wpływ na rozwój „własnej” jednostki samorządowej wywiera lub próbuje wywierać nacisk na instytucje publiczne. Oddolne włączanie się środowisk obywatelskich podporządkowane jest własnej logice, wychodzącej naprzeciw bezdusznym, biurokratycznym, zastałym i nieżyciowym działaniom systemu. Jednocześnie poszczególni członkowie zintegrowanej społeczności, oprócz wspólnej wizji mają także indywidualne wartości, potrzeby i cele, które próbują wynegocjować poprzez kompleksowe, wspólne działanie. W ramach działań obywatelskich mieści się zatem gra interesów na wielu płaszczyznach i w różnorakich sferach. Od polityki, reprezentowanej przez związki zawodowe, partie polityczne działające na pograniczu władzy i społeczności, po apolityczne organizacje nonprofit, mające na celu rozwiązywanie zdefiniowanych, konkretnych problemów społecznych poprzez pobudzanie, aktywizowanie i mobilizowanie do działań członków społeczności. Dzięki różnorodności form angażują w sferę swej działalności społeczności reprezentujące szeroki wachlarz dziedzin, celów, a także sił i poparcia, czyli bogaty kapitał ludzki i społeczny. Wielość inicjatyw na różnorodnych płaszczyznach lokalnych buduje szereg wartości obejmujących różne dziedziny dla zaspokojenia potrzeb zaangażowanych środowisk wspólnoty. Niewielki co prawda, acz stale rosnący, wskaźnik (z 21\% w 2002 r. do $28 \%$ w 2010 r.) obrazuje rosnącą aktywność w organizacjach obywatelskich ${ }^{13}$, które definiują bliskie im problemy i dążą do ich rozwiązania. Kształtowanie i wyrażanie poczucia odpowiedzialności za zachodzące procesy w demokratycznej rzeczywistości następuje zatem małymi krokami i misją władz publicznych jest tworzenie klimatu rozbudzania społecznej obywatelskości. Może to następować poprzez przekształcenie się administracji publicznej z roli administratora i zarządcy w koordynatora i partnera środowisk lokalnych.

Obecnie społeczeństwo obywatelskie wykazuje największą aktywność w czasie jednorazowych akcji typu Wielka Orkiestra Świątecznej Pomocy, marsze milczenia przeciw przemocy, popieranie protestów zbiorowych, akcje pomocy najbardziej potrzebującym oraz działalność lokalnych fundacji, np. Fundacji Ulicy Piotrkowskiej w Lodzi czy inicjatywy na rzecz odnowy lokalnych zabytków. Rzadziej występującą formą są komitety społeczne organizowane $\mathrm{w}$ celu realizacji wybranego zamierzenia wynikającego z potrzeb infrastruk-

\footnotetext{
${ }^{12}$ A. Potoczek, Administracja publiczna..., s. 17.

13 Aktywność Polaków w organizacjach obywatelskich w latach 1998-2010, Komunikat z badań. CBOS, BS/16/2010, Warszawa 2010.
} 
tury społecznej bądź technicznej. W raportach z badań $\mathrm{CBOS}^{14}$ warto zwrócić uwagę na rosnącą tendencję (z 50\% w roku 2002 do $72 \%$ w roku 2013) poglądów mówiących, że „ludzie tacy jak ja mogą wspólnie pomóc potrzebującym lub wspólnie rozwiązać wybrane problemy wspólnoty". Zrozumienie założeń decentralizacji w zakresie samodzielności i samorządności wspólnot stale ulega umacnianiu i powoduje wzrost poziomu zaangażowania społeczności obywatelskiej w kwestie samopomocy. Wykazywana aktywność obywatelska w pojedynczych, drobnych akcjach sugerować może zrozumienie przez społeczność wartości współdziałania i częstsze włączanie się w społecznie istotne sprawy, zadowalające efekty wcześniejszych przedsięwzięć mogą bowiem zachęcać do udziału w kolejnych. W ciągu analizowanych 10 lat liczba osób głoszących opinię, iż „współpraca przynosi większe efekty niż samodzielne działanie" wzrosła co prawda nieznacznie, bo z 78 do $81 \%$, ale przyznać należy, że jest to utrzymujący się wysoki poziom.

Dobre relacje aktorów lokalnych $\mathrm{z}$ decydentami lokalnymi oraz ich wzajemne zrozumienie rodzą gotowość do spontanicznych działań społecznych. Kolejne badania ${ }^{15}$ pokazują, że w roku 2010 aż 81\% dorosłych Polaków brało udział w akcjach inspirowanych celami społecznymi. Analizując podobne dane sprzed wstąpienia Polski do Unii Europejskiej, gdy aktywność Polaków sięgała poziomu $10 \%$, z czego wiodącymi inicjatywami były ruchy środowisk religijnych i placówek oświatowych ${ }^{16}$, wysnuć można wnioski o pozytywnej, wzrostowej tendencji zaufania do przemian demokratycznych i wzajemnej współpracy, kreujących integrację społeczną oraz nowatorskie postawy zaangażowania w kwestie wspólnoty samorządowej i partnerstwo lokalnych płaszczyzn obywatelsko-administracyjnych.

O społeczeństwie obywatelskim można mówić jednak dopiero wtedy, gdy obywatele występują masowo i dobrowolnie, a przy tym wspólnie podejmują wyzwania. Przytoczone wyniki badań sugerują rosnącą otwartość członków wspólnot terytorialnych i coraz bardziej aktywne postawy względem zaistniałych potrzeb. Jednakże kształtowanie szerokich zasobów społeczności obywatelskiej, z aktywnym jej udziałem w sprawach lokalnych, jest procesem długotrwałym, a jego poziomowi sprzyja przyjęta legislacja, doświadczenie struktur lokalnych i podatny grunt kreowany przez podmioty publiczne.

${ }^{14}$ Gotowość Polaków do wspołpracy w latach 2002-2012, oprac. K. Kowalczuk, Komunikat z badań. CBOS, BS/19/2012, Warszawa 2012.

${ }^{15}$ Aktywność społeczna Polaków - poziom, zaangażowanie i motywacje, Komunikat z badań. CBOS, BS/62/2011, Warszawa 2011.

${ }^{16}$ M.S. Szczepański, Od lokatora kamienicy do „czlowieka z Seatle”. Spoleczne podstawy ruchów politycznych, [w:] K. Bondyra, M.S. Szczepański, P. Śliwa [red.], Państwo, samorzą i..., s. 87. 


\section{Zakończenie}

Przyjęcie przez instytucje publiczne odpowiedniej strategii działania dla uzyskania pozytywnego ich postrzegania przez otoczenie tworzy podłoże do sięgania do zasobów lokalnego kapitału społecznego i włączania społeczeństwa $\mathrm{w}$ politykę rozwoju, począwszy od wspierania pojedynczych akcji aż do partycypacji w nakreślaniu kierunków rozwoju i czynnej realizacji przyjętych założeń. Zarówno wyniki przytoczonych powyżej badań, jak i literatura przedmiotu wskazują na wzrost świadomości społecznej dotyczącej pożytków płynących z zaangażowania i współdziałania w realizacji obranej drogi. Publiczne podmioty polityki rozwoju lokalnego tworząc dogodne płaszczyzny uczestnictwa społeczności w życiu jednostki samorządowej wspierają proces rozwoju lokalnego, a istnienie społeczeństwa obywatelskiego daje niezbędny asumpt do coraz bardziej efektywnego rozwoju lokalnego.

\section{Literatura}

Aktywność Polaków w organizacjach obywatelskich w latach 1998-2010, Komunikat z badań. CBOS, BS/16/2010, Warszawa 2010.

Aktywność społeczna Polaków - poziom, zaangażowanie i motywacje, Komunikat z badań. CBOS, BS/62/2011, Warszawa 2011.

Gotowość Polaków do współpracy w latach 2002-2012, oprac. K. Kowalczuk, Komunikat z badań. CBOS, BS/19/2012, Warszawa 2012.

Jewtuchowicz A., Terytorium i współczesne dylematy jego rozwoju, Wyd. UŁ, Łódź 2005.

Lewenstein B., Nowe paradygmaty rozwoju układów lokalnych, [w:] J. Kurczewska (red.), Oblicza lokalności. Różnorodność miejsc i czasu, Wyd. IFiS PAN, Warszawa 2006.

Nowakowska A., Polityka rozwoju gminy w okresie transformacji systemowej, [w:] A. Jewtuchowicz (red.), Strategiczne problemy rozwoju miast i regionów, Zakład Ekonomiki Regionalnej i Ochrony Środowiska Ut, Łódź 2000.

Parysek J.J., Podstawy gospodarki lokalnej, Wyd. Nauk. UAM, Poznań 2001.

Potoczek A., Administracja publiczna w procesie zarządzania rozwojem lokalnym i regionalnym, [w:] J. Rutkowski, D. Stawasz (red.), Zarządzanie rozwojem lokalnym, Fundacja Współczesne Zarządzanie, Białystok 2005.

Przygodzki Z., Znaczenie kapitału społecznego w rozwoju [w:] A. Jewtuchowicz (red.), Wiedza, innowacyjność, przedsiębiorczość a rozwój regionów, Wyd. UŁ, Łódź 2004.

Rymsza A., Klasyczne koncepcje kapitału społecznego, [w:] T. Kaźmierczak, M. Rymsza (red.), Kapitat społeczny. Ekonomia społeczna, Instytut Spraw Publicznych, Warszawa 2007.

Szczepański M.S., Od lokatora kamienicy do „człowieka z Seatle”. Spoleczne podstawy ruchów politycznych, [w:] K. Bondyra, M.S. Szczepański, P. Śliwa (red.), Państwo, samorząd i spoteczności lokalne. Piotr Buczkowski in memoriam, Wyd. WSB w Poznaniu, Poznań 2005.

Ustawa z dnia 8 marca 1990 roku o samorządzie gminnym, DzU, 1990, nr 16, poz. 95, z późn. zm.

Ustawa z 5 czerwca 1998 roku o samorządzie powiatowym, DzU, 1988, nr 91, poz. 578, z późn. zm.

Zasadzki W., Wybrane problemy lokalnej i regionalnej polityki gospodarczej, [w:] J. Kaja, K. Piech (red.), Rozwój oraz polityka regionalna i lokalna w Polsce, Wyd. SGH, Warszawa 2005.

Ziółkowski M., Społeczeństwo obywatelskie, transformacja i tradycja we wspólnotach lokalnych, [w:] K. Bondyra, M.S. Szczepański, P. Śliwa (red.), Państwo, samorząd i społeczności lokalne. Piotr Buczkowski in memoriam, Wyd. WSB w Poznaniu, Poznań 2005. 


\section{Streszczenie}

Dla efektywnego rozwoju lokalnego niezbędna jest współpraca władz samorządowych z funkcjonującymi na danym terenie mieszkańcami, podmiotami gospodarczymi oraz organizacjami pozarządowymi. Współpraca ta pozwala na zdobycie wiedzy o potrzebach środowiska lokalnego dostępnych zasobach i możliwościach ich wykorzystania. Społeczeństwo obywatelskie odgrywa zatem, obok władz lokalnych, rolę podmiotu rozwoju lokalnego partnersko współdecydującego o życiu wspólnoty.

\section{Summary}

\section{ROLE OF CIVIL SOCIETY IN LEADING POLICY OF LOCAL DEVELOPMENT}

For effecive local development, cooperation of local authorities with inhabitants of certain area, economic entities and non-governmental organisations, is necessary. This cooperation allows to achieve knowledge about needs of local environment, available resources and ways of using them. Civil society performs, next to local authorities, a role of being an entity of local development, together deciding about future life of community. 